\title{
OWNERSHIP STRUCTURE AND DEBT AS CORPORATE GOVERNANCE MECHANISMS: AN EMPIRICAL ANALYSIS FOR SPANISH SMES
}

\section{Ginés HERNÁNDEZ-CÁNOVAS ${ }^{1}$, Antonio MÍNGUEZ-VERA², Javier SÁNCHEZ-VIDAL ${ }^{3}$}

${ }^{1,3}$ Departamento de Economía Financiera y Contabilidad, Facultad de Ciencias de la Empresa, Universidad Politécnica de Cartagena. Calle Real 3, 30201 Cartagena, Spain ${ }^{2}$ Departamento de Organización de Empresas y Finanzas, Facultad de Economía y Empresa, Universidad de Murcia, Campus de Espinardo, 30100 Murcia, Spain Emails: 'Igines.hernandez@upct.es; ${ }^{2}$ minver@um.es (corresponding author); 3javier.sanchez@upct.es

Received 04 July 2013; accepted 22 October 2013

\begin{abstract}
The purpose of this paper is to analyze the relationship between ownership structure and indebtedness for a sample of 2,544 Spanish small and medium enterprises. A System Generalized Method of Moments methodology is applied to control for the heterogeneity and endogeneity problems. The finding shows a negative effect of several measures of ownership on debt ratio. Therefore, the presence of an individual as main shareholder has a positive effect on debt, while the presence of a corporation as main shareholder exerts a negative influence. As research implications, this paper includes the agency problem based on principal-principal conflicts to explain the capital structure of small and medium enterprises, going beyond traditional principal-agent conflicts. The main practical implications of the paper is that owners who seek equity financing can use the results of this study for understanding better why investors are reluctant to invest in their small and medium enterprises. Policymakers can use the results of this study to develop better policies and to promote better provision of information for all stakeholders. About the contribution of this study, we are not aware of any paper that uses a panel of small and medium enterprises operating in a French-civil law country to examine the relationship between indebtedness and three different proxies of the ownership structure.
\end{abstract}

Keywords: ownership structure, indebtedness, small and medium enterprises, System Generalized Method of Moments, Agency Theory, principal-principal perspective.

JEL Classification: G23, G24. 


\section{Introduction}

Since Berle, Means (1932) and Coase (1937), economists have been interested in the effects of the separation between ownership and control of corporate enterprises. Different objectives among diverse shareholders who own different percentages of the company and between shareholders and managers generate issues known as agency problems. The corporate governance literature has focused extensively on how large and diversified companies operating in countries with developed capital markets combine the use of their ownership and capital structures in order to minimize these agency problems (Aslan, Kumar 2012; Kuo et al. 2012; Morellec et al. 2012; Claessens, Yurtoglu 2013; Lin et al. 2013). However, we are not aware of any paper that uses a panel of small and medium enterprises (SMEs) operating in a French-civil law country to examine the relationship between indebtedness and three different proxies of the ownership structure, namely ownership concentration, the degree of control and the type of the main shareholder.

This paper tries to fill this gap in the literature studying the relationship between ownership and capital structures as corporate governance mechanisms used by a sample of Spanish SMEs to mitigate agency problems. This sample has several characteristics that differentiate our contribution from the existing empirical research. First of all, SMEs in civil law countries, compared to large companies in market based economies, have more concentrated ownership structures, are usually owner-managed, have worse access to capital markets, are less influenced by the external control mechanisms and their investors are weakly protected. In these circumstances it becomes very important to analyze the relationship between ownership and capital structures from the perspective of the agency problems arising when controlling shareholders try to expropriate wealth from minority shareholders. The section of this paper that addresses theory goes beyond traditional principal-agent conflict to incorporate this recent line of research, and include this agency problem based on principal-principal conflicts (Dharwadkar et al. 2000; Young et al. 2008). In addition to ownership concentration, our dataset allows us to use a dynamic measure of the degree of control, measured using the Cubbin-Leech index, and to examine the indebtedness preferences of two main types of shareholders, corporations and families. We apply panel data methodology and the System Generalized Method of Moments (GMM) technique because it is more powerful in controlling for unobservable heterogeneity and endogeneity, which are problems that have not been taken into account in most of the previous studies.

Our results show that indebtedness decreases for SMEs with more concentrated ownership structures, where controlling shareholders have more power, as well as in those firms having a corporation as a major shareholder. In our sample of Spanish SMEs, the principal-principal argument suggests that controlling shareholders use less debt in order to increase their financial flexibility and reduce bank supervision. We also find that having an individual or family group as main shareholder increases the debt ratio, which might indicate that the capital structure is adapted, either to reduce the agency problems arising between the controlling family and the minority shareholders or to allow family shareholders to maintain their control. 
The economic relevance of the empirical evidence presented in this paper lies on the crucial economic role played by SMEs (and by implication family owned and unlisted firms) in most developed and developing economies. SMEs account for about 99 percent of the total number of firms, provide 70 percent of the employment and 65 percent of the sales in Europe. In Spain, the numbers are very similar but the impact on employment is even higher ( 82 percent $)^{1}$.

The remainder of the paper is structured in four sections. In the next section, theoretical arguments and the previous empirical evidence are reviewed. The second section describes the data selection process, the characteristics of the sample and the methodology employed. The third section reports the results. The main conclusions are presented in the final section.

\section{Theory and previous evidence}

The ownership concentration and the degree of control are two measures of the power that shareholders can exercise over the insiders. The former refers to the equity of the main shareholders, while the degree of control takes into account the dispersal of the remaining shares.

Concentration of ownership allows shareholders to take a series of decisions that serve to exert their dominance in the firm. Palacín (1997) lists the following as crucial: to appoint the board members, to vote in general shareholder meetings, to participate in informal negotiations with management, to restrict the funds, to take legal action against directors and to influence hostile takeovers.

The second of the proposed measures, degree of control, is defined by Cubbin and Leech (1983) as the power to exercise greater discretion over decisions, including, in particular, the election of directors. As these authors point out, the traditional literature assumes that the majority shareholder has control of the property if their shareholding exceeds a certain percentage. However, Cubbin and Leech (1983) go further and argue that control depends on the degree of dispersion of the remainder of the ownership.

However, it is not clear that shareholder concentration and control grade are an efficient corporative governance mechanism because it is possible that higher concentration increases the probability of expropriation of the minority shareholders' wealth.

This assumption is important in the Spanish context. Spain is classified as a Frenchorigin civil law country by La Porta et al. (2002) and, in addition to weak investor protection, it is characterised by the presence of family ownership, concentrated share ownership and a reduced emphasis on external control mechanisms (Sánchez-Ballesta, Garcia-Meca 2005). This situation is more acute for SMEs than for listed firms. It is argued that these firms are frequently owned by a small and closed group of shareholders (Smith 2007) and the shareholders have a role of managers as well as owners (Abor, Adjasi 2007).

\footnotetext{
${ }^{1}$ Data obtained from the Observatory of European SMEs 2003.
} 
Thus, in this governance context the principal-principal conflict is more prominent than the classic principal-agent. This perspective was described by Dharwadkar et al. (2000) and Young et al. (2008) and it arises when the different principals do not share common interests. Shareholders can have different preferences for return, risk, control and motivations to invest.

Therefore, the main owners are in a better position to exert direct pressure on the board to secure their particular interests against those of the minority shareholders. Young et al. (2008) argue that principal-principal conflicts are greater when the ownership of the firm is concentrated in the hands of one shareholder or a small number of shareholders.

Another issue that influences the effectiveness of ownership structure as a control mechanism is the nature of the major shareholder. There is an extensive literature on the supervisory role of both corporate and individual or family investors.

Corporate investors can exert greater control in supervision for reasons of economies of scale. In addition, these investors may have more experience when it comes to exercising control, and can do so at less cost. However, corporations, whose investments are diversified, may have fewer incentives to exercise control. Therefore, managers or directors might either form an alliance with the corporate investors or exert some sort of implicit influence over them (depending on possible business that corporate investors may have with the firm), so that insider interests could still take priority over the shareholders' interests. In this way, corporate shareholders can use their power to expropriate the wealth of minority owners in favor of the corporate controlled shareholders. For example, corporate shareholders can sell inputs to the firm at an inflated price or can obtain funds from the subsidiary firm on terms that are better than those the capital market offers, because the controlling shareholder can use the subsidiary firm to providing credit guarantees (Li, Qian 2013).

An individual or family group, as a major investor, would intuitively have more incentive to exercise control over a corporation, as individuals or families would be less able to diversify their investments. These investors, however, will probably lack the advantages of corporate investors, such as economies of scale and experience. Setia-Atmaja et al. (2009) suggest that families tend to increase moral hazard conflicts between controlling and minority shareholders. For example, there may be a conflict between different branches of the family, and they may initiate "a 'race to the bottom' where one brother [successor] tries to tunnel resources out of the firm before another brother does." (Bertrand et al. 2008; Stewart, Hitt 2012). Young et al. (2008) identify several ways of expropriating the wealth of minority shareholders in family firms: appointing less-than-skilled family members in key positions, sibling rivalry, envy between family members and compensation not based on merit, among others.

The financial structure is another mechanism of internal control (Claessen, Yurtoglu 2013). It is based on the use of debt as an instrument to discipline and it has the following advantages (Jensen 1986; Palacín 1997): (a) Increasing debt may lead to more efficient conduct on the part of the managers, since their tenure depends on the survival 
of the firm (more leveraged firm has a higher probability of bankruptcy and this fosters more efficient behaviour), (b) if the level of investment and participation of internal stakeholders remains constant, increased indebtedness leads to a further concentration of ownership and therefore less incentive for additional consumption of resources of the firm in the form of perquisites (shirking, risk avoidance, excessive salary...), (c) increased debt reduces the free cash flows available to managers and therefore limits their discretionary behavior (Jensen 1986), and (d) high levels of debt facilitate liquidation of the firm through the bankruptcy process. In addition, the bank acquires private information about the borrowing firm that enables the bank to monitor the firm and implement the correct investment choices (Rajan 1992; Sharpe 1990). Periodic enforcement of debt covenants also performs a monitoring role. However, the use of debt can have negative effects, among which are the increased costs of bankruptcy and insolvency, the increase of agency conflicts between creditors and shareholders (Aslan, Kumar 2012), and the use of debt by managers to obtain control of the company with a smaller number of shares. Moreover, allowing the bank to develop a monopoly over business information, and being in a position to delay the granting of loans to the firm, may turn out to be costly.

Finally, there have been several works that have dealt with the interplay between the mechanisms used to solve the agency conflicts (for example, Hillier, McColgan 2002; Farinha 2003). Thus, the firm will choose the combination of different mechanisms which is most appropriate for each situation. One aspect that has recently attracted more interest is the relationship between ownership structure and debt (Lin et al. 2013; Morellec et al. 2012). If the concentration of ownership aligns the interests of insiders with outside owners, the firm will not need such a high level of debt. However, when the property is used to expropriate the wealth of minority shareholders, the percentage of debt should be greater. Al-Malkawi and Nizar (2007) and Faccio et al. (2000) find that highly levered firms retain their internal cash flows to meet the requirements of debt servicing and the controlling shareholder cannot expropriate the minority owners' wealth. In this context, a controlling shareholder can reduce the use of debt to avoid being monitored by the lenders.

In this context, it is of interest to test the relationship between debt ratio and ownership structure in Spanish SMEs. A positive relationship would imply that capital structure can help to reduce principal-principal conflicts, reducing the free cash flows and increasing the supervision of the controlling shareholders' actions. However, a negative relationship would show an entrenching of controlling shareholders, who may wish to avoid the supervision of lenders (Lin et al. 2013; Morellec et al. 2012).

Most of the existing empirical evidence has focused on listed firms, whereas SMEs have received less attention. Anderson and Reeb (2003) and Lin (2009) show a negative relationship between family shareholders and debt ratio. Setia-Atmaja et al. (2009) find that family firms employ higher debt levels compared to non-family firms. Kuo et al. (2012) show that shareholders with large blocks of shares and family shareholding do not affect leverage for a sample of 145 SMEs from Taiwan. Belghitar and Khan (2013) show that leverage reduces the cash available in UK SMEs and so diminishes the freedom of action of controlling shareholders. 


\section{Sample, data and methodology}

The sample includes SMEs that do not operate in the financial sector for the period 1998 to $2003^{2}$. The $\mathrm{SABI}^{3}$ database is employed. Once firms with no data and with erroneous data are excluded, as well as firms presenting extreme values, an unbalanced panel was constructed comprising 2,544 companies and 10,919 observations.

For this study the dependent variable is the debt ratio calculated as total debt to total assets and it is a proxy for access to debt financing for each firm (Saksonova 2006).

The concentration of shareholdings is calculated in several ways. The first method is to use the percentage of capital owned by the major shareholder (OWN1) .

Another indicator uses the Herfindahl index (H) (Herfindahl 1950), calculated as the sum of the squares of the shareholder ownership of equity capital, $H=\sum_{i=1}^{N} P_{i}^{2}$, where
$P_{i}$ is the percentage of shares held by shareholder $\mathrm{i}$. The importance of this index derives from the fact that it takes into account that concentration increases if the participation of any shareholder increases at the expense of a minor shareholder (Curry, George 1983).

The Cubbin-Leech (1983) index, ALPHA, is used as a measurement of the degree of control over the firm. It indicates the probability of the main shareholder controlling the firm, and depends on the degree of ownership and the dispersion of ownership among other shareholders. This index is based on the idea that a major ownership block can vote together strategically, while the rest of the shareholders either vote against or in favor of the main shareholder or vote in random coalitions. A probability is assigned to each of these possibilities.

Thus, for a firm with $N$ shareholders, with percentages of possession, $P_{1}, \ldots, P_{N}$, where $P_{i} \geq P_{i+1}$, and $\sum_{i=1}^{N} P_{i}=1$, the votes controlled by a main shareholder or coalition, $S$, formed by $n$ shareholders, would be $P(n)$. The votes of the remaining shareholders $i\left(q_{i}\right)$, where $i=n+1, \ldots, N$, would amount to $q_{i}=P_{i}$ or $q=0$ with the same probability. Therefore, the vote of shareholder $i$ will be a random variable with mean $P_{i} / 2$ and variance $P_{i}^{2} / 2$.

The votes of the primary coalition, taking this into account, will be given by the expression $q(S)=P(n)+\sum_{i=n+1}^{N} q_{i}$, which is a random variable with mean $P(n)+[(1-P(n)) / 2]=(P(n) / 2)+1 / 2$, and variance $\sigma(n)^{2} / 4$, where $\sigma(n)^{2}=\sum_{i=n+1}^{N} P_{i}^{2}$.

\footnotetext{
2 To define SME we have used the size criteria proposed by the European Commission (2003).

${ }^{3}$ System of Analysis of Iberian Balance Sheets, provided by Bureau Van Dijk.

${ }^{4}$ Including different measures to ensure robustness of analysis has become usual practice in research into ownership structure (see Gedajlovic, Shapiro 1998).
} 
The probability that the major coalition can obtain a majority is determined by the expression:

$$
\phi(n)=\operatorname{Pr}\left[q(S)>\frac{1}{2}\right]=1-\phi\left(\frac{\frac{1}{2}-\frac{P(n)}{2}-\frac{1}{2}}{\frac{\sqrt{\sigma(n)^{2}}}{2}}\right)=\phi\left(\frac{P(n)}{\sqrt{\sigma(n)^{2}}}\right),
$$

where $P(n)$ represents the votes of the major shareholder or coalition and $\sigma(n)^{2}$ the squared sum of the votes of the remaining shareholders.

If the expression for the Herfindahl index, $\mathrm{H}$, is substituted into $\sigma(n)^{2}$, the equation $\sigma(n)^{2}=H-P(n)^{2}$ is obtained. Finally, substituting $\sigma(n)^{2}$ into $\phi(n)$, the degree of control is defined as $\phi(n)=P(n) / \sqrt{H-P(n)^{2}}$.

Applying the central limit theorem, this index should follow a standard normal distribution, taking values between 0.5 and 1.0. Thus, the closer the value is to 1.0 , the greater the probability that the major shareholder or a major group of shareholders will control the company.

To measure the type of main shareholder, two binary variables are used, COR and IND, which take values of one when the main shareholder is a corporation (COR) or an individual (IND), and are zero otherwise.

We account for the heterogeneity across firms by including several firm-specific control variables in our model. Variables generally used as leverage determinants (Brav 2009) are profitability (ROA), growth opportunities (Q), intangible assets (INT), debt cost, size (logarithm of total assets), age of the firm (logarithm of the number of years since foundation) and Z Altman Index ${ }^{5}$.

Table 1 shows the descriptive statistics of all variables. The mean value of the concentration of the main shareholder is $62.7 \%$. This indicates the high level of ownership concentration in Spanish SMEs and the high incentive that the main shareholder can have to supervise insiders. The degree of control (ALPHA) takes a mean value of 0.915 . This number is higher than that provided by Mudambi and Nicosia (1998) for financial firms in the British market, 0.66, but very close to the 0.90 found by Köke (2000) in Germany, a civil law country. Thus, the higher ownership concentration observed in civil law countries indicates fewer coalitions are necessary to gain control.

The $51 \%$ of the firms are owned by an individual or family investor as main shareholder, while the $46 \%$ of the firms have a corporation as first investor.

\footnotetext{
${ }^{5}$ The Z-Altman index is a combination of five weighted business ratios that is used to estimate the likelihood of financial distress (these ratios measure the liquidity, profitability, productivity, insolvency and efficiency of the firm). Lower values of this index represent a significant risk due to their higher probability of insolvency.
} 
Table 1. Descriptive statistics

\begin{tabular}{lccccc}
\hline & Mean & Median & $\begin{array}{c}\text { Standard } \\
\text { deviation }\end{array}$ & Minimum & Maximum \\
\hline DEBT & 0.626 & 0.655 & 0.210 & 0.023 & 0.999 \\
\hline OWN1 & 0.627 & 0.524 & 0.290 & 0.001 & 1.000 \\
\hline H & 0.569 & 0.500 & 0.317 & 0.000 & 1.000 \\
\hline ALPHA & 0.915 & 0.976 & 0.099 & 0.602 & 1.000 \\
\hline COR & 0.462 & 0.000 & 0.499 & 0.000 & 1.000 \\
\hline IND & 0.514 & 0.500 & 0.500 & 0.000 & 1.000 \\
\hline SIZE & 14.247 & 16.188 & 0.856 & 6.916 & 17.274 \\
\hline LAGE & 2.911 & 2.928 & 0.599 & 0.812 & 4.655 \\
\hline INT & 0.406 & 0.009 & 0.083 & 0.003 & 0.855 \\
\hline COS & 0.028 & 0.024 & 0.034 & 0.000 & 1.186 \\
\hline ROA & 0.084 & 0.068 & 0.082 & -0.493 & 0.728 \\
\hline Q & 1.217 & 1.073 & 3.936 & 0.000 & 380.387 \\
\hline Z & 6.556 & 5.887 & 3.283 & -1.210 & 52.443 \\
\hline
\end{tabular}

Variables: DEBT (total debt over total assets), OWN1 (sum of the shares of the main shareholder), H (Herfindahl index), ALPHA (degree of control, measured by the Cubbin-Leech index), COR (binary variable that takes a value of 1 when the major shareholder is a corporation, and 0 otherwise), IND (binary variable that takes a value of 1 when the major shareholder is an individual or family, and 0 otherwise), SIZE (firm size), LAGE (firm age), INT (intangible assets to total assets), COS (financial expenses to total debt), ROA (return on assets, \%), Q (firm sales in year $t$ to firm sales in year $t-1$ ), Z (Z-Altman index).

Following theory, equation (2) is used to capture the relationship ownership structure and the debt of the firm:

$$
D E B T_{i t}=\beta_{0}+\beta_{1} I N D E P V A R_{i t}+\sum_{j=2}^{n} \beta_{j} O T H E R_{j i t}+\psi_{t}+\eta_{i}+\varepsilon_{i t},
$$

where INDEPVAR includes, alternatively, the ownership of the main shareholder (OWN1, model 1), the Herfindalh index (H, model 2), the control grade (ALPHA, model 3) and two dummies: the first will take a value of 1 when the main shareholder is a corporation (COR, model 4) and the second indicates the presence of a individual investor as main shareholder (IND, model 5). OTHER refers to the control variables, and $\psi_{t}, \eta_{i}$ and $\varepsilon_{i t}$ are time effects, unobserved individual heterogeneity and the error term, respectively.

In order to control for individual heterogeneity (highlighted by Himmelberg et al. 1999, among others), panel data methodology is employed to estimate these relationships by introducing an individual effect. In addition, time dummy variables are considered in the model to control for the macroeconomic effects on the dependent variables. The GMM proposed by Arellano, Bover (1995), and Blundell, Bond (1997) is applied. The System GMM technique is the estimation of a system of two simultaneous equations, one equation in levels and the other in first differences, and these simultaneous equa- 
tions are estimated with lagged level and first difference instruments. This methodology solves the problem of endogeneity arising when the right-hand side variables could be determined simultaneously with the dependent variable, and it allows to control for the individual effect.

\section{Results}

The results are presented in Tables 2 to 4 . Table 2 presents the effect of ownership structure variables on firm debt, while Tables 3 and 4 show the influence of the level of control and the type of main shareholder, respectively, on debt ratio ${ }^{6}$.

Table 2. GMM Panel Data Regression relative to the influence of ownership concentration variables on firm debt (DEBT)

\begin{tabular}{lcccc}
\hline \multicolumn{1}{c}{ Mariable } & Standard error & Coefficient & Standard error & Coefficient \\
\hline Constant & 0.138 & $0.625^{* * *}$ & 0.137 & $0.598^{* * *}$ \\
\hline OWN1 & 0.051 & $-0.151^{* * *}$ & & \\
\hline $\mathrm{H}$ & & & 0.046 & $-0.119^{* * *}$ \\
\hline SIZE & 0.008 & $0.030^{* * *}$ & 0.008 & $0.030^{* * *}$ \\
\hline LAGE & 0.007 & $-0.047^{* * *}$ & 0.007 & $-0.047^{* * *}$ \\
\hline INT & 0.066 & 0.022 & 0.066 & 0.023 \\
\hline COS & 0.103 & -0.096 & 0.100 & -0.096 \\
\hline ROA & 0.030 & $0.186^{* * *}$ & 0.030 & $0.187^{* * *}$ \\
\hline $\mathrm{Q}$ & 0.000 & $-0.001^{* * *}$ & 0.000 & $-0.001^{* * *}$ \\
\hline $\mathrm{Z}$ & 0.003 & $-0.040^{* * *}$ & 0.003 & $-0.041^{* * *}$ \\
\hline $\mathrm{z}_{1}$ & 0.000 & & 0.000 & \\
\hline $\mathrm{z}_{2}$ & 0.000 & & 0.000 & \\
\hline $\mathrm{m}_{2}$ & -0.460 & & -0.540 & \\
\hline Sargan & $169.78(157)$ & & & \\
\hline
\end{tabular}

Notes: $* * *$ denotes significance at the $1 \%$ level.

Variables: DEBT (total debt over total assets), OWN1 (sum of the shares of the main shareholder), $\mathrm{H}$ (Herfindahl index), SIZE (firm size), LAGE (firm age), INT (intangible assets to total assets), COS (financial expenses to total debt), ROA (return on assets, \%), Q (firm sales in year $t$ to firm sales in year $\mathrm{t}-1$ ), $\mathrm{Z}$ (Z-Altman index). $\mathrm{z}_{1}$ and $\mathrm{z}_{2}$ are two Wald tests of the joint significance of the reported coefficients and the joint significance of the time dummy variables, respectively (asymptotically distributed as $\lambda_{2}$ under the null of no relationship, probability is shown); $\mathrm{m}_{2}$ is a second-order serial correlation test using residuals in first differences, asymptotically distributed as $\mathrm{N}(0,1)$ under the null of no serial correlation; Sargan is a test of the over-identifying restrictions, asymptotically distributed as $\lambda_{2}$ under the null of no correlation between the instruments and the error term, degrees of freedom in parentheses.

${ }^{6}$ In order to control for potential multicollinearity we computed the Variance Inflation Factor and verified that it was never above the critical value of 5 . 
Table 2 indicates a negative and significant relationship between the percentage of shares owned by the main shareholder (OWN1) and the indebtedness (DEBT). This evidence may indicate that a controlling shareholder is trying to avoid lender supervision and it can entail an expropriation of minority shareholders (in accordance with principal-principal conflict, Denis and Mihov 2003). However, it also possible that, firms with a concentrated ownership structure, as SMEs often are, can have conflicts between owners and creditors, due to the level of information asymmetry in this type of firm. This circumstance can provoke a negative relationship between debt and ownership (Anderson, Reeb 2003). Also, a controlling shareholder may be risk averse and may mitigate firm risk by employing less debt in the firm's capital structure (Anderson, Reeb 2003).

The same result is found when ownership structure is measured by the Herfindahl index $(\mathrm{H})$. Firms with more concentrated ownership have lower levels of debt. So, this relationship does not depend only on the proportion of the shares owned by the main shareholders but also on the concentration level of all the property.

For the control variables we obtain a positive sign for the size of the firm, SIZE, and return on assets, ROA; negative for the age of the firm, LAGE, growth opportunities and $\mathrm{Z}$ index; and no significant results for the intangibles and financial expenses variables. Size shows the right sign, as the larger the company is, the fewer problems of information asymmetry and thus, a higher probability of being more suitable to receive credit. The sign coincides with the results of Frank and Goyal (2009) and Kayo and Kimura (2011). With respect to age, a positive sign is expected a priori because the older the company is, the more information the company provides and the more willing the creditors will be to provide funds. In contrast with this hypothesis, Michaelas et al. (1999) argue that the older the company is, the more opportunities the company has had to retain earnings and thus, the more probable it is that there has been a decrease of debt, and so, a negative sign would be expected. The evidence supports this latter argument. The negative sign for the $\mathrm{Z}$ index is contrary to what was expected but may be explained by the fact that, in the computation of this variable, equity itself is part of the index, and more equity is associated with less debt. A similar result was obtained by Bartholdy and Mateus (2011). We also find a positive effect of return on assets, ROA, in accordance with the arguments of Modigliani and Miller (1958), who stated that higher profitability makes the tax shield of debt more attractive for firms ${ }^{7}$. The negative sign for the growth opportunities variable agrees with the arguments by Fama and French (2002) who argue that firms with larger growth opportunities may decide to adopt low

\footnotetext{
${ }^{7}$ Ownership can be considered an instrument of managerial discipline. It can also affect performance and performance may affect leverage, as a more profitable company tends to lower its debt, according to the pecking order theory of capital structure. Although the multivariate regression controls for all the covariation between variables, we have controlled for this indirect relationship by running all the regressions for different subsamples grouped by similar profitability values and find similar results to those obtained for the whole sample.
} 
debt levels. In this way, and in the presence of asymmetric information, they will avoid possible problems of underinvestment ${ }^{8}$.

The two Wald Tests $\left(z_{1}\right.$ and $\left.z_{2}\right)$ show the joint significance of the reported coefficients and of the time dummies, respectively. To check for potential misspecification of the models, the $\mathrm{m}_{2}$ statistic was used, which tests for lack of second-order serial correlations in the first-difference residuals. In the tests made in this study, the hypothesis of second-order serial correlation is always rejected. Finally, Sargan's Test confirms the absence of correlation between instruments and error terms in all of the models and it therefore confirms the suitability of the instruments used in the estimations.

Table 3 shows the relationship between the Cubbin-Leech index (ALPHA) and debt ratio. A shareholder can obtain the control of the firm having a low percentage of the shares if the other shareholders each own only small amounts of the firm. On the other hand, an owner with a relative high level of ownership can have difficulty gaining control of the firm if the other shareholders own a large proportion of shares.

This measure is more complex that the measures of firm ownership concentration and make the results of the study more robust. As with the results shown in Table 2, we find a negative and significant coefficient for the Cubbin-Leech index. In this way, more controlled firms can demonstrate more opportunistic behavior on the part of the main shareholder. However, as noted earlier, the negative relationship between power and debt can also come from the restriction of funds by the lender or from the risk aversion of the controlling shareholder. On this point, we show that the level of indebtedness not only depends of ownership concentration but also of the degree of control.

Table 4 reports the results for the effect of the type of main shareholder on firm debt. First, it is observed that COR and IND variables have a significant influence on debt ratio and therefore they are useful in explaining firm debt. The presence of a corporation as main shareholder has a negative effect on debt ratio in line with the results obtained in Tables 2 and 3.

For the individual dummy variable (IND), we find a positive association with debt ratio. This type of firm usually has a higher aversion to risk (H. DeAngelo, L. DeAngelo 2000) and a higher level of information asymmetry (Attig et al. 2006). This circumstance provokes a negative relationship between debt and family control in firms. However, the positive sign may indicate a desire to maintain the control of the family group. It seems that the theory of risk aversion and credit rationing associated with the information asymmetry do not determine the level of debt in Spanish SMEs. The principal-principal conflict seems to be the cause of the negative relationship found in Tables 2 and 3. In this case, a family firm can mitigate the problem of expropriation of minority shareholders wealth by using more debt in order to maintain control over the

\footnotetext{
${ }^{8}$ The evidence for the control variables for the other models is very similar, and so, and in order not to be repetitive, we will not discuss the results for these variables again. The fact that coefficients and significances show such stability when changing the other explanatory variables for the different equations is a further indication that multicollinearity is not a problem.
} 
firm. Evidence provided by the coefficients of COR and IND show that the impact of the major shareholder being a corporation/an individual or family is a $6.4 \%$ decrease/a $6.5 \%$ increase respectively in the percentage of debt over total assets. These percentages are not by any means inconsiderable, even though they are less than the impact of a $100 \%$ increase in ROA (18.5\%). The profitability variable has always been a very influential variable in any analysis about financial variables in the company. The only other variable, apart from ROA, with higher coefficients (although not significant) than COR and IND is financial expenses, which seems logical. The overall evidence shows our study variables are important and have a substantial influence on the companies' financial policies.

Table 3. GMM Panel Data Regression relative to the influence of the grade of control on firm debt (DEBT)

\begin{tabular}{lcc}
\hline & Model (3) & \\
\hline Variable & Standard error & Coefficient \\
\hline Constant & 0.188 & $1.010^{* * *}$ \\
\hline ALPHA & 0.135 & $-0.483^{* * *}$ \\
\hline SIZE & 0.008 & $0.027^{* * *}$ \\
\hline LAGE & 0.007 & $-0.042^{* * *}$ \\
\hline INT & 0.072 & 0.037 \\
\hline COS & 0.118 & -0.089 \\
\hline ROA & 0.031 & $0.187^{* * *}$ \\
\hline Q & 0.000 & $-0.001^{* * *}$ \\
\hline $\mathrm{Z}$ & 0.003 & $-0.041^{* * *}$ \\
\hline $\mathrm{z}_{1}$ & 0.000 & \\
\hline $\mathrm{z}_{2}$ & 0.000 & \\
\hline $\mathrm{m}_{2}$ & -0.380 & \\
\hline Sargan & $169.28(158)$ & \\
\hline
\end{tabular}

Notes: $* * *$ denotes significance at the $1 \%$ level.

Variables: DEBT (total debt over total assets), ALPHA (degree of control, measured by the CubbinLeech index), SIZE (firm size), LAGE (firm age), INT (intangible assets to total assets), COS (financial expenses to total debt), ROA (return on assets, \%), Q (firm sales in year to firm sales in year $t-1$ ), $Z$ (Z-Altman index). $z_{1}$ and $z_{2}$ are two Wald tests of the joint significance of the reported coefficients and the joint significance of the time dummy variables, respectively (asymptotically distributed as $\lambda_{2}$ under the null of no relationship, probability is shown); $\mathrm{m}_{2}$ is a second-order serial correlation test using residuals in first differences, asymptotically distributed as $\mathrm{N}(0,1)$ under the null of no serial correlation; Sargan is a test of the over-identifying restrictions, asymptotically distributed as $\lambda_{2}$ under the null of no correlation between the instruments and the error term, degrees of freedom in parentheses. 
Table 4. GMM Panel Data Regression relative to the influence of type of main shareholder on firm debt (DEBT)

\begin{tabular}{lcccc}
\hline \multicolumn{2}{c}{ Model (4) } & \multicolumn{2}{c}{ Model (5) } \\
\hline Variable & Standard error & Coefficient & Standard error & Coefficient \\
\hline Constant & 0.136 & $0.541^{* * *}$ & 0.137 & $0.473^{* * *}$ \\
\hline COR & 0.014 & $-0.064^{* * *}$ & & \\
\hline IND & & & 0.013 & $0.065^{* * *}$ \\
\hline SIZE & 0.009 & $0.031^{* * *}$ & 0.009 & $0.031^{* * *}$ \\
\hline LAGE & 0.007 & $-0.047^{* * *}$ & 0.007 & $-0.046^{* * *}$ \\
\hline INT & 0.074 & 0.033 & 0.076 & 0.058 \\
\hline COS & 0.090 & -0.121 & 0.089 & -0.128 \\
\hline ROA & 0.031 & $0.185^{* * *}$ & 0.030 & $0.188^{* * *}$ \\
\hline Q & 0.000 & $-0.000^{* * *}$ & 0.000 & $-0.000^{* * *}$ \\
\hline $\mathrm{Z}$ & 0.003 & $-0.039^{* * *}$ & 0.003 & $-0.039^{* * *}$ \\
\hline $\mathrm{z}_{1}$ & 0.000 & & 0.000 & \\
\hline $\mathrm{z}_{2}$ & 0.000 & & 0.000 & \\
\hline $\mathrm{m}_{2}$ & -0.600 & & -0.620 & \\
\hline Sargan & $171.35(157)$ & & $165.17(157)$ & \\
\hline & & & & \\
\hline
\end{tabular}

Notes: $* * *$ denotes significance at the $1 \%$ level.

Variables: DEBT (total debt over total assets), COR (binary variable that takes a value of 1 when the major shareholder is a corporation, and 0 otherwise), IND (binary variable that takes a value of 1 when the major shareholder is an individual or family, and 0 otherwise), SIZE (firm size), LAGE (firm age), INT (intangible assets to total assets), COS (financial expenses to total debt), ROA (return on assets, $\%$ ), Q (firm sales in year $t$ to firm sales in year $t-1$ ), $Z$ (Z-Altman index). $z_{1}$ and $z_{2}$ are two Wald tests of the joint significance of the reported coefficients and the joint significance of the time dummy variables, respectively (asymptotically distributed as $\lambda_{2}$ under the null of no relationship, probability is shown); $\mathrm{m}_{2}$ is a second-order serial correlation test using residuals in first differences, asymptotically distributed as $\mathrm{N}(0,1)$ under the null of no serial correlation; Sargan is a test of the over-identifying restrictions, asymptotically distributed as $\lambda_{2}$ under the null of no correlation between the instruments and the error term, degrees of freedom in parentheses.

\section{Conclusions}

This paper analyzes the interrelationship between debt and ownership structure in Spanish SMEs from the Agency Theory perspective. Spanish corporate structure is based on French civil law. It is characterized by a high concentration of shareholdings, a low level of legal protection for shareholder interests, and little operation of external control mechanisms. In this context, the traditional principal-agent conflict may not be the most relevant framework to explain the relationship between ownership structure and debt. In SMEs, ownership and control are often not separated and the main prob- 
lem is the expropriation of the minority shareholders' wealth by the controlling owner (principal-principal conflict). The controlling shareholder may try to avoid lender supervision by using less debt.

This paper shows a negative relationship between these two variables. Firms with more concentrated ownership (measured by the percentage of shares of the major shareholder and by the Herfindalh index) have less debt in their capital structure. In addition, an increased probability that the main shareholder can control the firm (measured by the Cubbin-Leech index) also reduces indebtedness. So, it seems that, from the principalprincipal perspective, the controlling shareholder will try to avoid debt in order to expropriate the wealth of minority owners.

Finally, the presence of a corporation as main shareholder reduces the debt ratio, while firms need more debt to reduce the agency conflicts when the major owner is an individual or family group. It is possible that, in family firms, the preference for keeping control from the family group implies a willingness to accept higher levels of debt. This circumstance can increase the external supervision of these firms and reduce the principal-principal agency conflict.

The evidence presented in this paper has clear implications for firms and policy makers. Owners who seek equity financing can use the results of this study to understand better why investors are reluctant to invest in their SMEs. Owners can use the results to adopt corporate governance mechanisms that reduce wealth expropriation from minority shareholders, such as appointing external directors on the board and extending the good governance codes to their SMEs.

The flow of capital from providers to users of capital is required for a healthy and dynamic economy. Policymakers can use the results of this study to develop better policies and to promote better provision of that information for all stakeholders to help them understand each other more fully, enhancing the financing processes of SMEs.

\section{Acknowledgement}

The authors acknowledge financial support by Fundación CajaMurcia, Fundación Séneca (Project 15403/PHCS/10), and by Ministerio de Ciencia e Innovación (Project ECO2011-29080).

\section{References}

Abor, A.; Adjasi, C. K. D. 2007. Corporate governance and the small and medium enterprises sector: theory and implications, Corporate Governance 7(2): 111-122.

http://dx.doi.org/10.1108/14720700710739769

Al-Malkawi, H.; Nizar, H. 2007. Determinants of divident policy in Jordan, an aplication of Tobin model, Journal of Economics and Administrative Sciences 23(2): 44-70.

http://dx.doi.org/10.1108/10264116200700007

Anderson, R.; Reeb, D. M. 2003. Founding family ownership and firm performance: evidence from the S\&P 500, Journal of Finance 58: 1301-1329. http://dx.doi.org/10.1111/1540-6261.00567 
Arellano, M.; Bover, O. 1995. Another look at the instrumental variable estimation of errorcomponents models, Journal of Econometrics 68: 29-51.

http://dx.doi.org/10.1016/0304-4076(94)01642-D

Aslan, H.; Kumar, P. 2012. Strategic ownership structure and the cost of debt, Review of Financial Studies 25(7): 2257-2299. http://dx.doi.org/10.1093/rfs/hhs062

Attig, N.; Fong, W.; Gadhoum, Y.; Lang, L. H. P. 2006. Effects of large shareholding on information asymmetry and stock liquidity, Journal of Banking \& Finance 30: 2875-2892.

http://dx.doi.org/10.1016/j.jbankfin.2005.12.002

Bartholdy, J.; Mateus, C. 2011. Debt and taxes for private firms, International Review of Financial Analysis 20(3): 177-189. http://dx.doi.org/10.1016/j.irfa.2011.02.012

Belghitar, Y.; Khan, J. 2013. Governance mechanisms, investment opportunity set and SMEs cash holding, Small Business Economics 40(1): 59-72. http://dx.doi.org/10.1007/s11187-011-9366-z

Berle, A. A.; Means, G. C. 1932. The modern corporation and private property. New York: Macmillan.

Bertrand, M.; Johnson, S.; Samphantharak, K.; Schoar, A. 2008. Mixing family with business: a study of Thaibusiness groups and the families behind them, Journal of Financial Economics 88: 466-498. http://dx.doi.org/10.1016/j.jfineco.2008.04.002

Blundell, R.; Bond, S. 1997. Initial conditions and moment conditions in dynamic panel data models, Journal of Econometrics 87: 115-143. http://dx.doi.org/10.1016/S0304-4076(98)00009-8

Brav, O. 2009. Access to capital, capital structure, and the funding of the firm, The Journal of Finance 64(1): 263-308. http://dx.doi.org/10.1111/j.1540-6261.2008.01434.x

Claessens, S.; Yurtoglu, B. B. 2013. Corporate governance in emergency markets: a survey, Emergency Markets Review 15: 1-33. http://dx.doi.org/10.1016/j.ememar.2012.03.002

Coase, R. H. 1937. The nature of the firm, Economica NS 4: 386-405.

http://dx.doi.org/10.1111/j.1468-0335.1937.tb00002.x

Cubbin, J.; Leech, D. 1983. The effect of shareholding dispersion on the degree on control in British companies: theory and measurement, Economic Journal 93: 35-69.

http://dx.doi.org/10.2307/2232797

Curry, B.; George, K. D. 1983. Industrial concentration: a survey, Journal of Industrial Economics 31(3): 203-255. http://dx.doi.org/10.2307/2097885

DeAngelo, H.; DeAngelo, L. 2000. Controlling shareholders and the disciplinary role of corporate payout policy, Journal of Financial Economics 56: 153-207.

http://dx.doi.org/10.1016/S0304-405X(00)00039-8

Denis, D.; Mihov, V. 2003. The choice among bank debt, non-bank private debt and public debt: evidence from new corporate borrowings, Journal of Financial Economics 70: 3-28.

http://dx.doi.org/10.1016/S0304-405X(03)00140-5

Dharwadkar, R.; George, G.; Brandes, P. 2000. Privatization in emerging economies: an agency theory perspective, Academy of Management Review 25(3): 650-69.

European Commission. 2003. Recommendation of 6 May concerning the definition of micro, small and medium-sized enterprises. Document number C (2003) 1422, 361/EC.

Faccio, M.; Lang, L. H. P.; Young, L. 2000. Dividends and expropriation, European Financial Management Journal 91(1): 54-80.

Fama, E.; French, K. 2002. Testing trade-off and pecking order predictions about dividends and debt, Review of Financial Studies 15: 1-33. http://dx.doi.org/10.1093/rfs/15.1.1

Farinha, J. 2003. Dividend policy, corporate governance and the managerial entrenchment hypothesis: an empirical analysis, Journal of Business Finance and Accounting 30: 1173-1209. http://dx.doi.org/10.1111/j.0306-686X.2003.05624.x 
Frank, M. Z.; Goyal, V. K. 2009. Capital structure decisions: which factors are reliably important?, Financial Management 38(1): 1-37. http://dx.doi.org/10.1111/j.1755-053X.2009.01026.x

Gedajlovic, E.; Shapiro, D. 1998. Management and ownership effects: evidence from five countries, Strategic Management Journal 19: 533-553.

http://dx.doi.org/10.1002/(SICI)1097-0266(199806)19:6<533::AID-SMJ957>3.0.CO;2-\#

Herfindahl, O. C. 1950. Concentration in the U.S. steel industry. Dissertation. Columbia University.

Hillier, D.; McColgan, P. 2002. Insider ownership and corporate value: an empirical test from the United Kingdom corporate sector, in European Financial Management Association (EFMA) Meeting, June 26-19, 2002, London.

Himmelberg, C. P.; Hubbard, R. G.; Palia, D. 1999. Understanding the determinants of managerial ownership and the link between ownership and performance, Journal of Financial Economics 53: 353-384. http://dx.doi.org/10.1016/S0304-405X(99)00025-2

Jensen, M. C. 1986. Agency cost of free cash flow, corporate finance and takeovers, American Economic Review 76: 323-329.

Kayo, E. K.; Kimura, H. 2011. Hierarchical determinants of capital structure, Journal of Banking \& Finance 35: 358-371. http://dx.doi.org/10.1016/j.jbankfin.2010.08.015

Köke, J. 2000. Control transfer in corporate Germany: their frequency, causes and consequences, ZEW Discussion Paper (00-67).

Kuo, H.; Wang, L.; Liu, H. 2012. Corporate governance and capital structure: evidence for Taiwan SMEs, Review of Economics and Finance 2: 43-58.

La Porta, R.; Lopez de Silanes, F.; Shleifer, A.; Vishny, R. W. 2002. Investor protection and corporate valuation, Journal of Finance 57: 1147-1170. http://dx.doi.org/10.1111/1540-6261.00457

Lin, S. 2009. The effect of family shareholders on firm leverage, in The European Financial Management Association (EFMA) International Conference, August 20-22, 2009, Bergen, Norway.

Lin, C.; Ma, Y.; Malatesta, P.; Xuan, Y. 2013. Corporate ownership structure and the choice between bank debt and public debt, Journal of Financial Economics 109(2): 517-534.

http://dx.doi.org/10.1016/j.jfineco.2013.03.006

Li, J.; Qian, C. 2013. Principal-principal conflicts under weak institutions: a study of corporate takeover in China, Strategic Management Journal 34: 498-508.

http://dx.doi.org/10.1002/smj.2027

Michaelas, N.; Chittenden, F.; Poutziouris, P. 1999. Financial policy and capital structure choice in U.K. SMEs: empirical evidence from company panel data, Small Business Economics 12(2): 113-130. http://dx.doi.org/10.1023/A:1008010724051

Modigliani, F.; Miller, M. 1958. The cost of capital, corporation finance and the theory of investment, American Economic Review 48(3): 261-297.

Morellec, E.; Nikolov, B.; Schürhoff, N. 2012. Corporate governance and capital structure dynamics, Journal of Finance 67(3): 803-848. http://dx.doi.org/10.1111/j.1540-6261.2012.01735.x

Mudambi, R.; Nicosia, C. 1998. Ownership structure and firm performance: evidence from the UK financial services industry, Applied Financial Economics 8: 175-180.

http://dx.doi.org/10.1080/096031098333159

Observatory of European SME's. 2003. SME's in Europe. 2003. European Comission No 7.

Palacín, M. J. 1997. El mercado de control de empresas: el caso español. Barcelona: Ariel Economía.

Rajan, R. 1992. Insiders and outsiders: the choice between relationship and arms-length debt, Journal of Finance 47: 1367-400. http://dx.doi.org/10.1111/j.1540-6261.1992.tb04662.x 
Saksonova, S. 2006. The analysis of company's capital and evaluation of factors, which influence creation of the optimal capital structure, Journal of Business Economics and Management 7(3): 147-153.

Sánchez-Ballesta, J. P.; García-Meca, E. 2005. Audit qualifications and corporate governance in Spanish listed firms, Managerial Auditing Journal 20: 725-738.

http://dx.doi.org/10.1108/02686900510611258

Setia-Atmaja, L.; Tanewski, G. A.; Skully, M. 2009. The role of dividends, debt and board structure in the governance of family controlled firms, Journal of Business Finance \& Accounting 36: 863-898. http://dx.doi.org/10.1111/j.1468-5957.2009.02151.x

Sharpe, S. 1990. Asymmetric information, bank lending and implicit contracts: a stylized model of customer relationships, Journal of Finance 45: 1069-1087.

Smith, C. W. 2007. On governance and agency issues in small firms, Journal of Small Business Management 45(1): 176-178. http://dx.doi.org/10.1111/j.1540-627X.2007.00206.x

Stewart, A.; Hitt, M. A. 2012. Why can't a family business be more like a nonfamily business? Modes of professionalization in family firms, Family Business Review 25(1): 58-86.

http://dx.doi.org/10.1177/0894486511421665

Young, M. N.; Peng, M. W.; Ahlstrom, D.; Bruton, G. D.; Jian, Y. 2008. Corporate governance in emerging economies: a review of the principal-principal perspective, Journal of Management Studies 5: 196-220. http://dx.doi.org/10.1111/j.1467-6486.2007.00752.x

Ginés HERNÁNDEZ-CÁNOVAS is Associate Professor of Finance at the Faculty of Business Studies, Technical University of Cartagena (Spain). His current research interests include corporate finance management, capital structure and relationship lending. His empirical work has centred around the financial decision-making process within SMEs. He has published in refereed international journals such as Small Business Management, International Small Business Journal and Small Business Economics.

Antonio MíNGUEZ-VERA is PhD in Economics and Business (Technical University of Cartagena). At present he is Associate Professor of Financial Economics at the University of Murcia. His main research topics are related to gender diversity, corporate finance and corporate governance. He has published in refereed international journals such as Journal of Business Ethics, International Journal of Human Resource Management and International Review of Financial Analysis.

Javier SÁNCHEZ-VIDAL is Associate Professor (Business Finance) at the Faculty of Business Studies, Technical University of Cartagena (Spain). Phd in Economics and Business (Technical University of Cartagena). Master of Money, Banking and Finance at the Sheffield University Management School at the Sheffield University (UK). Graduate in Economics at the University of Murcia (Spain). Fields of interest - Econometrics - Corporate Finance - Cash Holdings. He has published in refereed international journals such as Journal of Business Economics and Management, Journal of Banking and Finance, Economic Modelling, Journal of Business Research and Review of Quantitative Finance and Accounting. 